\title{
IAMJ
}

INTERNATIONAL AYURVEDIC MEDICAL JOURNAL

\section{A STUDY ON MEDICINAL VALUE OF KATPHALA (SOHPHIE - LOCAL KHASI NAME) COMMONLY PRACTICED BY KHASI TRADITIONAL HEALER FOR VARIOUS AILMENTS: A REVIEW WITH AYURVEDIC PERSPECTIVES}

\author{
$\underline{\text { Verity Markhap }}^{1}$, $\underline{\text { Khagen Basumatary }}^{2}$, $\underline{\text { Amit Hassan Mazumder }}^{3}$, Spasterlin Nongrem $^{4}$
}

${ }^{1}$ P.G.T, P.G. Dept Samhita Siddhanta,

${ }^{2}$ Prof. \& Head, P.G. Dept Samhita Siddhanta,

${ }^{3}$ P.G.T, P.G. Dept Samhita Siddhanta

Govt. Ayurvedic College and Hospital, Guwahati- 781014, Assam, India

${ }^{4}$ Traditional Health Practitioner, Advisor, Meba-ai Tribal Health \& Wellness Centres, Shillong, Meghalaya, India

Corresponding Author: markhapverity@gmail.com

\section{https://doi.org/10.46607/iamj4608102020}

(Published online: October 2020)

Open Access

(C) International Ayurvedic Medical Journal, India 2020

Article Received: 30/09/2020 - Peer Reviewed: 02/10/2020 - Accepted for Publication: 04/10/2020

Check for updates

\begin{abstract}
Khasi tribe, largest tribes of Meghalaya, northeastern part of India possesses an immense knowledge and belief on their folklore medicinal practice. They inhibit their art of healing from their forefather, and it is being passed on since ages. Numerous herbs are utilized and practiced for their specific desired effect. One such medicinal plant is Myrica Nagi (Myricaceae) commonly known as Box Myrtle or Katphala as per Ayurveda. This plant is very well known among the community for its multiple medicinal remedies, locally known as Sohphie its fruit is being consumed as pickle and refreshing juice. The other part used are prepared into various formulations for the desired therapeutic effect. Irrespective of the traditional usage, it is widely mentioned in the classical texts of Ayurveda. A clear identification and detail analysis of this herb as per Traditional knowledge and Ayurveda texts would aid in better understand of its distinctive and multiple therapeutic effect.
\end{abstract}

Keywords: Myrica Nagi, Katphala, Sohphie, Khasi community, traditional medicine, Ayurveda 


\section{INTRODUCTION}

India considered a goldmine for medicinal plants have always been known for its glorious tradition of the science of healing. Ayurveda, the organized system of medicine emerged around $6000(\mathrm{BCE})^{[1]}$ from India is reported to have over 20,000 drug plant drug formulation listed in ayurvedic pharmacopeia. In addition, nearly 60,000 are believed to be existing in the folk practices and tribal knowledge ${ }^{[2]}$. There are over 53 million tribal people in India belonging to 550 communities of 227 ethnic group. They inhibit about 5000 forested villages or lead a nomadic life in the forest ${ }^{[3]}$. Each community having each own social and cultural identity. In Meghalaya, the tribal communities are around 12 in number, out of which Khasi tribe is the largest of Meghalaya ${ }^{[4]}$. This ethno-linguistic group highly intact to their rich culture and tradition from ages possess an immense knowledge and belief on their folklore practices. One such medicinal plant is Myrica nagi (Myricaceae) commonly known as Box Myrtle or Katphala as per Ayurveda. This plant is very well known among the community for its multiple medicinal remedies, its fruit is being consumed as pickle and refreshing juice in diet. The other part used are prepared into various formulations for the desired therapeutic effect. M. Nagi synonymous with M. esculenta is reported to be the only species of genus Myri$c a$ found in India ${ }^{[5]}$. Irrespective of the traditional usage, it is widely mentioned in the classical texts of Ayurveda. The present article is an attempt to summarize the Ayurvedic and Khasi folklore practices approach in -relation to the medicinal properties of the plant and its therapeutic utilization.

\section{Material and Methods}

Field survey in Ribhoi, East Khasi hills and West Khasi hills district of Meghalaya, India was conducted by consulting with the experienced elderly folklore practitioner of those district and information regarding the traditional use of the katphala (Myrica nagi) was retrieved. The information gathered is re-evaluated and compared with the established system of herbal medicine i.e. Ayurveda and data of recent updates published in various scientific articles.

\section{Taxonomy:}

\section{Katphala}

Botanical Name: Myrica nagi, M.esculenta Buch Ham Family: Myricaceae

Classical Name: Katphala

Sanskrit name: Kataphala, Katphala, Mahavalkala

Regional names: Kayaphal (Hin.,Mar.,Guj.), Katphal (Beng), Marudam (Tam.), Kaidaryumu (Tel.), Kirishivani (Kann.), Marut(Mal.), Ajuri,Udulvark, Kandul (Arb.); Darsish an (Pers); Box myrtle (Eng.).

Geographical Distribution: Subtropical Himalaya from the Ravi Eastwards, Khasia hills, Sylhet and south to Singapore, Malay islands, China, Japan.[6]

\section{Description}

A small or moderate-sized evergreen tree up to $5 \mathrm{ft}$. girth and 40ft. high. Bark dark brown or blackish, rather rough and exfoliating in irregular small woody scales. Wood pale brown, heavy, compact and hard. Blaze 5.1 inches, soft not fibrous, deep reddish brown, often with paler streaks, juice turning dark purple on the blade of a knife.

Young shoots, petioles and inflorescence brown tomentose. Leaves $4-8$ by $1.2-2$ inches, oblanceolate or oblanceolate- oblong, acute, entire, undulate, based gradually narrowed coriaceous glabrous or nearly so when mature, dark green above, rather glossy on both sides(surfaces). Male spikes 3-5 inches long, arranged racemosely on a common axillary stalk 1.5-4 inches long, bract orbicular, stamens 3-6. Female spikes axillary erect 5.1 inches long. Drupe 4 inches long sessile, ellipsoid, ovoid, stone red, wrinkled, scaly, succulent, flesh red when ripe and pitted stones. ${ }^{[7]}$ 
Flowering and fruiting time: Flowers usually in October - December and its fruits ripens during late summer season.

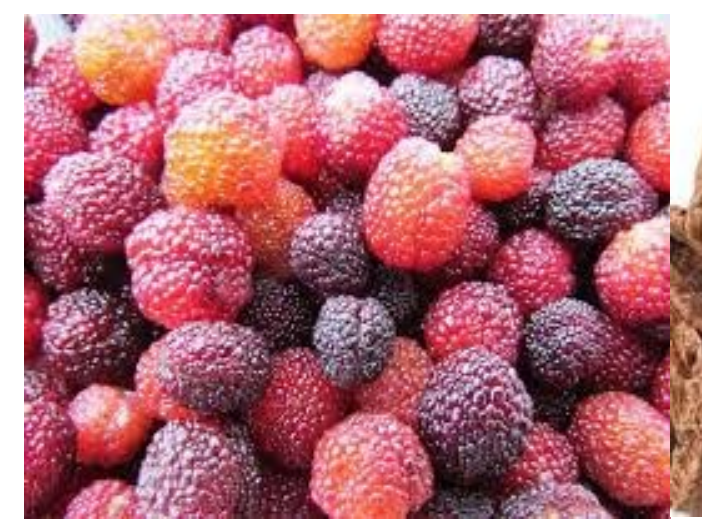

(a) Fruit

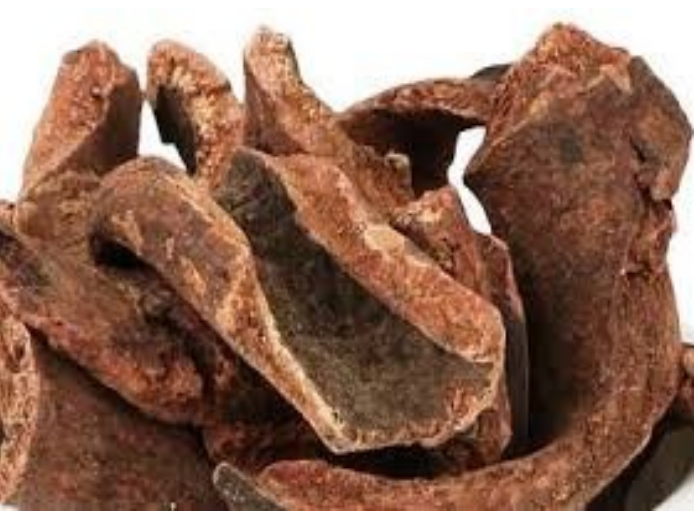

(b) Bark

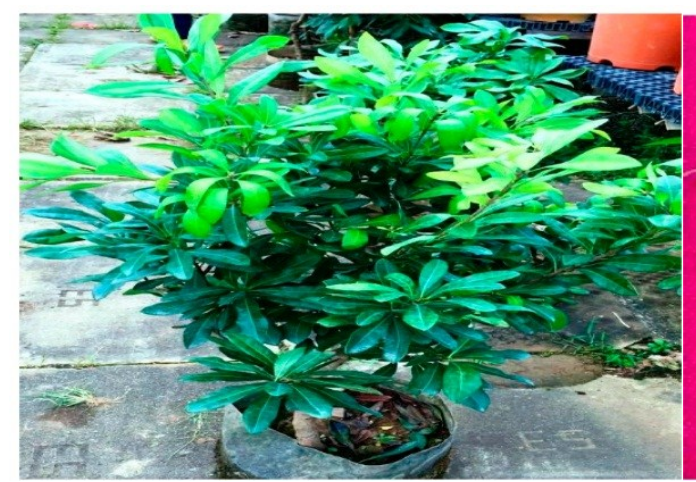

(c) Whole Plant

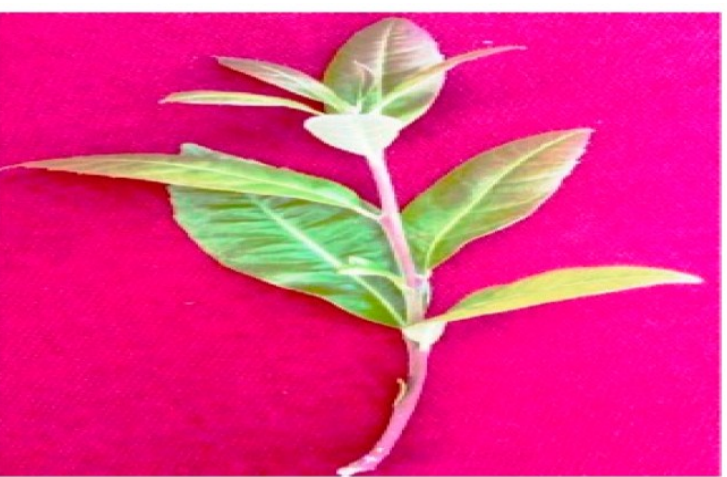

(d) Leaf
Chemical composition: Bark contains tannin, saccharine matter and salts. The ground bark yields a colouring principle named myricetin. ${ }^{[8]}$

Pharmacodynamics:

\section{Properties and Action:}

Table 1: properties and action as per classical texts.

\begin{tabular}{|c|c|c|}
\hline Karma & Roga & Gana \\
\hline $\begin{array}{l}\text { Sukrashodhana, Tivra sirovirechana, } \\
\text { kandughna - Sothahara, Kothaprasamana, } \\
\text { Garbhasayasankocha, } \\
\text { nadibalya, Dedanasthapana- Dipana-grahi-sulaprasamana, } \\
\text { Sandhaniya-Sothahara, Kaphanihsaraka- } \\
\text { svasahara, Mutrasangrahaniya, Twakdosha- } \\
\text { hara, Sandhaniya-Hrdya. }\end{array}$ & 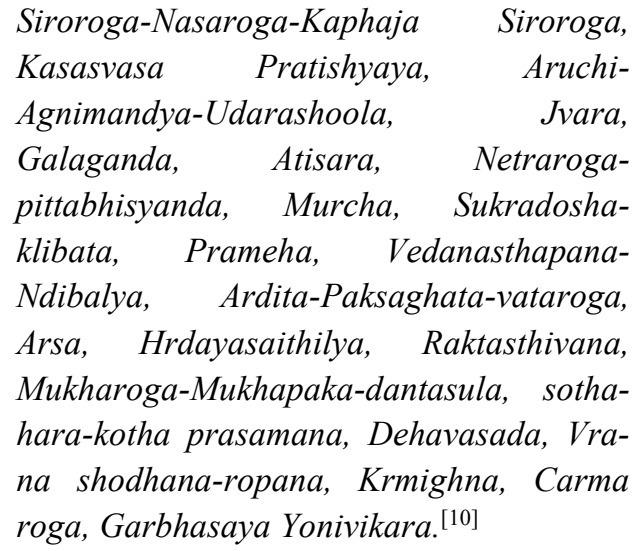 & $\begin{array}{l}\text { Sukrashodhana, Sandhani- } \\
\text { ya, Vedanasthapana } \\
\text { (Charaka Samhita) } \\
\text { Lodhradi, Surasadi } \\
\text { (Sushruta Samhita) }\end{array}$ \\
\hline
\end{tabular}

Guna: Rasa - Katu, Tikta, Kasaya; Guna - Laghu, Tikshna; Virya - Usna; Vipaka - Katu;

Upayukta anga (Part used): Twak

Doshakarma: Vatakaphashamaka ${ }^{[9]}$ 


\section{References in Ayuveda:}

1. Kayadeva Nighantu, Oshadhi varga 11/37-39

2. Bhavaprakasha Nighantu, Haritakyadi Varga 181

3. Raja nighantu

4. Cakradatta,41-9;11/23 - katphaladi kwatha; Katphaladi choorna

5. Charaka samhita, Chikitsa Sthana, 10, 4-Raktapitta, Atisara

6. Vrndamadhava, 1-112 - shleshmika jwara

7. Sushruta Samhita, Uttara 10/12; 26/22 - Pittabhishyanda; Katphala Nasya

Various formulation: ${ }^{[1]}$

1. Pushayanuga Choorna

2. Guggulwasava

3. Irimedadi taila

4. Khadiradi vati

5. Mahakukkuta mamsa taila

6. Devdarvyadi kashaya

7. Katphaladi churna

8. Nograin capsule

9. Anjal tablet

Sohphie - Use As Per Cultural And Traditional Medicine:

Sohphie also known as Myrica nagi is one of the famous seasonal fruits found in the Khasi and Jaintia hills of Meghalaya. It is not just known for its cultural importance but as overall health treasure due to its medicinal property. Traditional healers of Meghalaya have been utilizing its different part for different healing purposes, and this has been followed since ages.
Interacting with the local practitioners and other research studies following data was retrieved:

There are four types of Myrica nagi as per the locals (genus Myrica, Species - not known):

1. Phiejynroh 2. Phiebyrtha 3. Phienam 4. Phielyia

- Phie jynroh is the biggest in size with a small seed., when ripen it is brown in colour.

- Phiebyrtha is medium sized but has bigger seed compared to Phiejynroh

- Phienam is smaller than Phiebyrtha and Phielyia is the smallest.

- Phiebyrtha is yellowish, Phienam is light maroon and Phielyia is deep maroon in colour.

\section{Cultural Use}

- Fishing: The powder of bark is tied in a cloth and put in flowing river for the purpose of killing the fish in ponds or rivers. (Especially Sohphie nam and Phielyia)

- Bark - extracted tannins used as a tanning and dyeing agent(yellow). ${ }^{[12]}$

- Fruits - stored as Pickle in every house of Meghalaya. Also stored as jam, syrups and refreshing drinks. $^{[13]}$

- $\quad$ Tree is used for wood and timber.

It changes the soil environment - other plants cannot grow within a certain distance around the tree. As per a study it is said to grow well in nitrogen depleted soils, mixed forests, agricultural lands. ${ }^{[14]}$

Medicinal Use: Used part: Bark, fruit, root and flower.

Table 2: Medicinal utilization as per traditional healers.

\begin{tabular}{|c|c|c|c|}
\hline S1. No. & Formulation & Dosage & Indication \\
\hline 1. & $\begin{array}{l}\text { Fresh fruit with its juice - fruit pulp is cut and macer- } \\
\text { ated. } \\
\text { Can be stored for 4-6hours }\end{array}$ & $\begin{array}{l}1 / 2 \quad \text { cup }(30 \mathrm{ml}) \\
\text { twice daily }\end{array}$ & $\begin{array}{l}\text { Clears the gastrointestinal tract, indigestion, } \\
\text { intestinal worms, gastritis, diarrhea, hemorrhoid, } \\
\text { constipation. } \\
\text { Also, in dysmenorrhea and other menstrual com- } \\
\text { plaints. } \\
\text { During hot summer as a refreshing drink. }\end{array}$ \\
\hline 3. & $\begin{array}{l}\text { Bark powder: Bark is dried and pounded into fine } \\
\text { powder. }\end{array}$ & $\begin{array}{l}1 \text { tsf with hot wa- } \\
\text { ter thrice daily }\end{array}$ & $\begin{array}{l}\text { Respiratory tract infections, cough, fever, indi- } \\
\text { gestion, abdominal colic, hemorrhoids. } \\
\text { Tooth ache, mouth ulcer- gargling of the powder }\end{array}$ \\
\hline
\end{tabular}




\begin{tabular}{|c|l|l|l|}
\hline & & & $\begin{array}{l}\text { with hot water. } \\
\text { Fresh bark soaked in hot water and used for Lo- } \\
\text { cal application in skin diseases. }\end{array}$ \\
\hline 4. & Roots: Fresh roots pounded and made into paste. & $\begin{array}{l}\text { Quantity suffi- } \\
\text { cient }\end{array}$ & $\begin{array}{l}\text { Local application in skin disorders } \\
\text { Also cough, asthma and Cholera (1/2 tsf with hot } \\
\text { water). }\end{array}$ \\
\hline 5 & Flower: oil preparation & $\begin{array}{l}\text { Quantity suffi- } \\
\text { cient }\end{array}$ & $\begin{array}{l}\text { Local application in paralysis, ear drops in ear- } \\
\text { ache. }\end{array}$ \\
\hline
\end{tabular}

\section{CONCLUSION}

This wonder plant Sohphie popular among the Khasi tribe when studied as per the various classical text and research studies claims to possess the multipurpose pharmacological actions like anti-inflammatory, antioxidant, analgesic, anti-microbial, antiseptic, antispasmodic properties etc. making it an important treasured medicinal plant of the community. It is highly potent drug coming under Ganas like Sukrashodhana, Sandhaniya, Vedanasthapana, Lodhradi and Surasadi as per the Acharyas, it also acquires multiple karma and rogaghnata making it the most desirable in various disorders and formulations. Apart from its cultural importance like fishing, agricultural use for timber and wood it also forms an integral part of the traditional healing system for its medicinal importance. In its surge of reaching the verge of getting extinct due to habitat and climate change, there should be a conservative approach towards it in the agriculture and the community. Hence emphasizing that it can set a new platform for the researcher and pharmaceutical sciences. When Ayurvedic reference about Katphala (Sohphie) was initiated with the traditional healers, it resulted in a acquiring a new comprehensive insight about the plant. Therefore, also promoting the idea of Integrating both perspective of Ayurveda and traditional knowledge together for a better cause.

\section{REFERENCES}

1. Ernst, E. (2007). Complementary therapies for pain management: an evidence-based approach. Elsevier Health Sciences.

2. Mohandas, K. (2004). Indian medicinal plants in: Food, medicine IK and IPR National seminar on Indian Medicinal Plants, 17.

3. Prakash, J. W., Raja, R. D., Anderson, N. A., Williams, C., Regini, G. S., Bensar, K., ... \& Das, S. S. M. (2008). Ethnomedicinal plants used by Kani tribes of
Agasthiyarmalai biosphere reserve, southern Western Ghats.

4. Zirihi, G. N., Mambu, L., Guédé-Guina, F., Bodo, B., \& Grellier, P. (2005). In vitro antiplasmodial activity and cytotoxicity of 33 West African plants used for treatment of malaria. Journal of ethnopharmacology, 98(3), 281-285.

5. Haridasan k, Rao RR. Forest flora of Meghalaya. Caprifoliaceae to Salicaceae. Dehradun (India): Bishen Singh Mahendra Pal Singh; 1987.

6. Kirtikar, K.R \& Basu, B.D, Indian Medicinal plants, text. Vol.3, second edition; 2005, pg. no. 2350

7. Dr. Gyanendra Pandey, vol 2. Dravyaguna Vigyana,2012, pg. no. 208

8. Dr. K. M Nadkarni's, Indian Materia Medica with Ayurvedic, Unani \& Home remedies Vol.1, page no. 828

9. Prof. D.S Lucas, Dravyaguna-Vijńāna, Study of Dravya-Materia Medica, vol-2, pg. no. 664

10. Dr. Gyanendra Pandey, vol 2. Dravyaguna Vigyana, 2012, pg. no. 209,210

11. https://www.easyayurveda.com/2017/06/21/boxmyrtle-katphala/

12. Sun, D.; Zhao, Z.; Wong, H.; Foo, L.Y. Tannins and other phenolics from Myrica esculenta bark. Phytochemistry 1988, 27, 579-583. [Google Scholar]

13. Makdoh, K.; Lynser, M.B.; Pala, K.H.M. Marketing of Indigenous Fruits: A Source of Income among Khasi Women of Meghalaya, North East India. J. Agric. Sci. 2014, 5, 1-9. [Google Scholar] [CrossRef]

14. Bhatt, I.D.; Rawal, R.S.; Dhar, U. Improvement in seed germination of Myrica esculenta Buch. Ham. Ex D. Don- A high value tree species of Kumanun Himalaya, India. Seed Sci. Technol. 2000, 28, 597-605.

\section{Source of Support: Nil Conflict of Interest: None Declared}

How to cite this URL: Verity Markhap et al: A Study On Medicinal Value Of Katphala (Sohphie - Local Khasi Name) Commonly Practiced By Khasi Traditional Healer For Various Ailments: A Review With Ayurvedic Perspectives. International Ayurvedic Medical Journal \{online\} 2020 \{cited October, 2020 $\quad$ Available from: http://www.iamj.in/posts/images/upload/4853_4857.pdf 